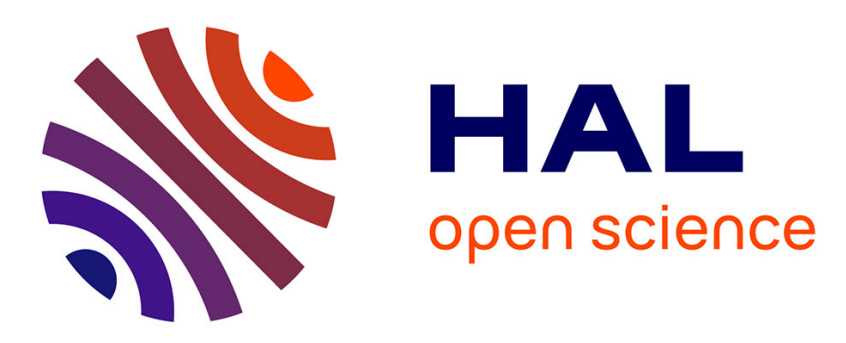

\title{
Measuring the social value of local public goods: an Empirical Analysis within Paris Metropolitan Area
}

Alessandra Michelangeli, Nicolas Gravel, Alain Trannoy

\section{To cite this version:}

Alessandra Michelangeli, Nicolas Gravel, Alain Trannoy. Measuring the social value of local public goods: an Empirical Analysis within Paris Metropolitan Area. Applied Economics, 2006, 38 (16), pp.1945-1961. 10.1080/00036840500427213 . hal-00581888

\section{HAL Id: hal-00581888 \\ https://hal.science/hal-00581888}

Submitted on 1 Apr 2011

HAL is a multi-disciplinary open access archive for the deposit and dissemination of scientific research documents, whether they are published or not. The documents may come from teaching and research institutions in France or abroad, or from public or private research centers.
L'archive ouverte pluridisciplinaire HAL, est destinée au dépôt et à la diffusion de documents scientifiques de niveau recherche, publiés ou non, émanant des établissements d'enseignement et de recherche français ou étrangers, des laboratoires publics ou privés. 


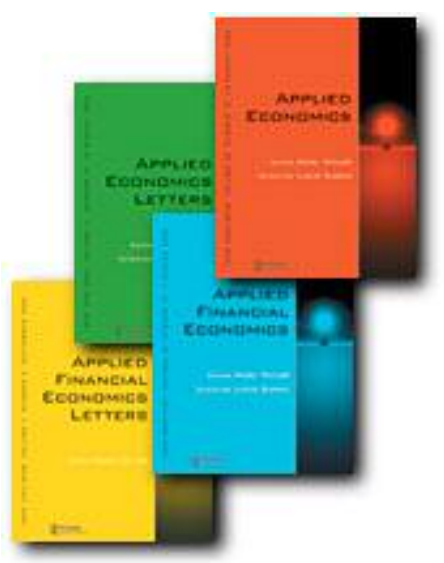

Measuring the social value of local public goods: an Empirical Analysis within Paris Metropolitan Area

\begin{tabular}{|r|l|}
\hline Journal: & Applied Economics \\
\hline Manuscript ID: & APE-04-0165.R1 \\
\hline Journal Selection: & Applied Economics \\
\hline Date Submitted by the \\
Author: & 07-Feb-2005 \\
\hline JEL Code: & $\begin{array}{l}\text { C49 - Other < C4 - Econometric and Statistical Methods: Special } \\
\text { Topics < C - Mathematical and Quantitative Methods, D61 - } \\
\text { Allocative Efficiency|Cost Benefit Analysis < D6 - Welfare } \\
\text { Publicly Provided Goods < H - Public Economics, R21 - Housing } \\
\text { Demand < R2 - Household Analysis < R - Urban, Rural, and } \\
\text { Regional Economics }\end{array}$ \\
\hline Keywords: & hedonic, public goods \\
\hline
\end{tabular}




\title{
Measuring the Social Value of Local Public Goods: An
}

\section{Empirical Analysis within Paris metropolitan area}

\author{
Nicolas Gravel, Alessandra Michelangeli ${ }^{\dagger}$ and Alain Trannoy ${ }^{\ddagger}$ \\ (this version) January 15th 2005
}

Jel Classification Number: C4, D6, H4, R2

\begin{abstract}
We use a non-linear hedonic model to estimate the implicit marginal prices of 17 local public goods in a Paris suburban area on an original data set of some 8200 housing units. The results reveal a robust effect of local public school quality (mesured both by the fraction of junior high school students that are at least 2 years behind grade level and the student/teacher ratio) on house prices. It is observed that housing owners' marginal willingness to pay for reducing commuting time is roughly similar for public transportation than for car transportation. Another noticeable result is the complete capitalization of local taxes at a discount rate of 3,5\%. An illustration of the potential usefulness of the results for Cost-Benefit analysis is also provided.
\end{abstract}

\footnotetext{
${ }^{*}$ CSH (Delhi) and IDEP-GREQAM, 2, Aurangzeb Road, 110011 Delhi, India, nicolas.gravel@csh-delhi.com.

${ }^{\dagger}$ THEMA, Université de Cergy-Pontoise, 33, Bd du Port, 95011 Cergy-Pontoise, Cedex, France, alexandra.michelangeli@eco.u-cergy.fr

${ }^{\ddagger}$ IDEP-GREQAM and EHESS, Centre de la Vieille Charité, 2, rue de la Charité, 13002 Marseille Cedex, France trannoy@ehess.univ-mrs.fr
} 


\section{Introduction}

It is well-known that if a good is traded in a competitive market, the social value of a 'small' additional quantity of the good is measured by its market price, if the initial distribution of wealth, which gives rise to the competitive equilibrium, is considered optimal. A problem that arises when one wants to apply this principle to the evaluation of 'small' public projects is that most goods supplied by such projects (such as quality of public schools, public parks, etc.) are not directly traded on competitive markets. Either for their intrinsic property (non-rivalry in consumption and non-excludability) or for exogenous political reasons, they belong to the category of public goods. How can the authority in charge of producing these goods obtain the relevant information about their social value?

When public goods are local, the 'hedonic' or - more revealingly -implicit price theory popularized by Rosen (1974) provides an answer to that question. Recall that hedonic price theory views a housing as a bundle of utility-bearing characteristics, some of which being the public goods to which the occupation of the house give access. Accordingly, this theory interprets the price of a house as the market evaluation, by a hedonic price function, of the particular package of characteristics embodied in it. Although local public goods themselves are not traded on competitive markets, units of housing which give access to these local public goods are. Like for private goods, therefore, the increase in housing price brought about by a "small" increase in the quantity of a public good can be interpreted as the marginal social value of this public good and be used as such in cost-benefit analysis (see e.g. Scotchmer $(1985 ; 1986)$ and Kanemoto (1988) for a complete discussion of the use of hedonic prices in cost-benefit analysis $)^{1}$.

\footnotetext{
${ }^{1}$ The local character of the information conveyed by empirical estimates of a hedonic price function, to which we stick in the present paper, is worth emphasizing. Only under very specific assumptions (such as those considered
} 
Empirical estimations of housing hedonic prices functions including local public goods have been abundant in North America in the last thirty years (see Kiel and McClain (1996) or Lynch and Rasmussen (2001) for example). They have been much more rare in Europe (see however Cheshire and Sheppard (1995) and Ginsburgh and Waelbroeck (1998)) and this paper is primarily intended as a contribution toward closing the huge gap that separates North America from Europe in terms of empirical knowledge of the value attached by citizens to specific local public goods. In our view, improving knowledge on this matter in Europe is a necessary step in understanding the differences between Europe and North America in terms of public good provision and financing.

A particular area where this comparison is likely to be instructive is education. Many hedonic studies performed in the United States $^{2}$ have found a significant negative relationship between the housing price and the pupil/teacher ratio at local public schools. This ratio is interpreted as an indicator of the "objective" input devoted into the children's human capital production process by the public authorities. However, it is certainly not the only input of the human capital production function. Another input, which has been the object of a an important theoretical and empirical literature ${ }^{3}$ is the quality of the 'peers' with whom the pupil interacts. However the American public school system makes the observed negative relationship between housing prices and pupil/teacher ratios somewhat difficult to interpret. This difficulty arises because, in the United States, public schools are managed and partially or wholly financed at the local (county or state) level. As a result, the across-county differences in public subsidies received in Bartik (1987)) can an estimation of the hedonic price function provide global information on preferences and technology. A thorough discussion of these issues is provided in Ekeland et al (2004).

${ }^{2}$ See for instance Bogart and Cromwell (1997) and Black (1999).

${ }^{3}$ See e.g. Arnott and Rowse (1987), Hanuscheck (1986). 
by schools tend to be heavily correlated with the sociological characteristics of the counties. For this reason an observed relationship between housing prices and pupil/teacher ratios in the United States could in part reflect a concern for avoiding bad peers rather than a preference for smaller class sizes per se. Ideally, one would like to disentangle the household's valuation of the relative impact of the two inputs on human capital accumulation.

Our data set and the institutional framework of the public school system in France enables us to decompose these differing effects to some extent. The public school system is managed by the central government which pursues an egalitarian aim. As a result, differences between the public subsidies received by different schools are small and they tend to be slightly biased in favor of the relatively poor cities. These institutional features of the French public school system suggest that cross-cities variations in the pupil/teacher ratio are less likely to be related to variations in the quality of the 'peer group' in France than in the U.S. As it happens, our data contains a plausible indicator of the academic quality of the peers that a given pupil will encounter when attending local public school and hence enable us to disentangle the peer group effects from the input effect.

Another kind of local public good that is likely to be valued differently in Europe and in the US is public transportation. In Paris outskirts, 50\% of inhabitants go to work by car, $28 \%$ use public transportation and $12 \%$ use both systems. ${ }^{4}$ These figures are typically much higher than in US metropolitan areas. As it turns out, very few empirical hedonic studies have included variables that measure access to public or private transportation network. Given the role devoted to transportation in standard urban theory (see e.g. Fujita 1999), this neglect is somewhat surprising.

\footnotetext{
${ }^{4}$ Source: INSEE census 1999.
} 
We provide in this paper an estimation of a hedonic price function on an original data set of some 8200 observations on individual dwelling prices collected from the 33 largest cities of Val d'Oise (an administrative area that counts 1 million of inhabitants in the north-west of Paris) over the 1985-1993 period. By contrast to many studies in the literature, we include a large number (17) of public goods, among which are the quality of local public schools (measured both by the fraction of junior high school students that are at least 2 years behind grade level and the student/teacher ratio), geographical characteristics (distance from Roissy airport, geographic elevation of the location, the fraction of the city's area devoted to recreational land, etc.) and cultural/commercial infrastructure (number of historical buildings, playground fields, retail stores, public entertainment centers, etc. relative to the number of inhabitants). Also included are local tax rates on housing as well as measures of the commuting time (both by public transportation and by car) during rush hour. We also have at our disposal information on many housing-specific characteristics such as the size of the housing, the availability of a balcony, an equipped kitchen, and the like.

The plan of the rest of the paper is as follows. In the next section, we sketch the theoretical model. In the third section, we present our data set and the estimation method. The results are discussed and interpreted in the fourth section. The fifth section uses our hedonic estimates to examine an actual expenditure program designed by the French government to reduce school delinquencies in a few cities covered by our sample and recall the conditions that enable one to interpret partial derivatives of housing prices with respect to public goods characteristics as marginal social values of the public goods. The sixth section concludes. 


\section{Theoretical model}

The model described here is standard and is presented for the sake of completeness. Consider the problem of a household who chooses a quantity of a perfectly divisible private good (say money) and exactly one unit of housing. Alternative units of housing are assumed to be completely differentiated by their content in $K$ implicit (but observable) characteristics. As in Rosen (1974), a unit of housing can thus be thought of as a vector in the non-negative orthant of the $K$ dimensional Euclidean space. It is further assumed that the number and variety of different cities and housing units is sufficiently large for the choice among city-specific and housingspecific characteristics to be assumed continuous 'for all practical purposes' (Rosen (1974)). This assumption is rather stringent in the context of location choice and should, at best, be seen as an approximation. The interpretation given to the empirical model estimated in this paper would not hold if the choice among alternative housing units was assumed to be discrete.

Let $\mathbf{X}$ denote the (closed and convex) set of all conceivable packages of the $K$ characteristics. The household's preferences for the various combinations of private goods and housing characteristics are represented by a twice continuously differentiable strongly quasi-concave and weakly increasingly monotonic utility function $U: \mathbf{X} \rightarrow \mathbb{R}_{+}$with image $u$. Every unit of housing with combination of characteristics $\mathbf{c} \in \mathbb{R}_{+}^{K}$ has a market price which can be thought of as the image of $\mathbf{c}$ under a function $h: \mathbb{R}_{+}^{K} \rightarrow \mathbb{R}_{+}$. The function $h$ is commonly referred to as a hedonic price function. It assigns a price to every unit of housing as a function of its characteristics. We assume that $h$ is strictly monotonically increasing and differentiable with respect to every characteristic. The household is assumed to act on the premises that $h$ is given and independent from its location and housing-specific package choice. ${ }^{5}$

\footnotetext{
${ }^{5}$ Questions related to the existence and interpretation of $h($.$) in a (spatial) general equilibrium with production$
} 
Taking the private good as the numéraire, and assuming that the household is initially endowed with $y$ units of the private good, the decision problem faced by the household is:

$$
\max _{(\mathbf{c}, x)} U(\mathbf{c}, x)
$$

subject to

$$
x+h(\mathbf{c}) \leq y \text { and }(\mathbf{c}, x) \in \mathbf{X}
$$

where $x \in \mathbb{R}_{+}$denote the quantity of private good consumed by the household. Assuming that $\mathbf{X} \cap\left\{(\mathbf{c}, x) \in \mathbb{R}_{+}^{K+1}: x+h(\mathbf{c}) \leq y\right\}$ has a non-empty interior in $\mathbb{R}_{+}^{K+1}$ and given the properties of $h$ and $\mathbf{X}$, it is clear that this program has a solution. A solution $\left(\mathbf{c}^{*}, x^{*}\right)$ satisfies the first order conditions

$$
\frac{\frac{\partial U\left(\mathbf{c}^{*}, x^{*}\right)}{\partial c_{k}}}{\frac{\partial U\left(\mathbf{c}^{*}, x^{*}\right)}{\partial x}}=\frac{\partial h\left(\mathbf{c}^{*}\right)}{\partial c_{k}}
$$

for every characteristic $k$ chosen in strictly positive quantity in the interior of $\mathbf{X}$. As usual, the left hand side of this equation is the marginal rate of substitution between the $k^{\text {th }}$ characteristic and the private good. It gives the maximal quantity of private good that the household is willing to give up in order to have access to an additional (arbitrarily small) amount of the $k^{\text {th }}$ characteristic. It gives the household's marginal willingness to pay for the $k^{\text {th }}$ characteristic which, at the households' optimal choice, is equal to the hedonic price $\frac{\partial h\left(\mathbf{c}^{*}\right)}{\partial c_{k}}$ of this $k^{\text {th }}$ characteristic.

\section{Empirical implementation of the model}

Since theory offers no guidance with respect to the form of the function $h$ it is important to allow for some flexibility in the choice of the empirical functional form (see e.g. Cropper et al. (1988) are beyond the scope of this paper and are not addressed. The reader may consult Mas-Colell (1975) and Ellikson (1979). 
or Rasmussen and Zuehlke (1990) for further discussion on the issue). We do so by specifying a Box-Cox (1964) transformation of the dependant variable. ${ }^{6}$ The empirical model we estimate is therefore, for every observation $j=1, \ldots, N$,

$$
p_{j}(\lambda)=\sum_{k=1}^{K} \beta_{k} c_{k j}+\varepsilon_{j}
$$

with

$$
\begin{aligned}
p_{j}(\lambda) & =\frac{p_{j}^{\lambda}-1}{\lambda} \text { if } \lambda \neq 0 \\
& =\ln p_{j} \text { otherwise }
\end{aligned}
$$

where

$p_{j}$ denotes the price of the unit of housing $j$,

$c_{k j}$ denotes the quantity of the $k$ th characteristics possessed by the $j$ th housing (with the convention that $c_{1 j}=c_{1 i}=1$ for all $\left.i, j=1, \ldots, N\right)$, and

$\varepsilon_{j}$ is a random term assumed to be identically, normally and independently distributed across observations with mean 0 and variance $\sigma_{i}^{2}=\sigma_{j}^{2}=\sigma^{2}$ for all $i, j$.

We shall later on refer to $p_{j}(\lambda)$ as to the transformed price.

The empirical function (3) enables one to calculate easily the first and second derivatives of the price with respect to the various characteristics. From (3), the first partial derivative of the housing price with respect to the $k$ th characteristic in observation $j$ is given by

$$
\frac{\partial p_{j}}{\partial c_{k}}=\beta_{k} p_{j}^{1-\lambda}
$$

which implies that the $k$ th characteristic is a positive amenity if $\beta_{k}$ is positive. The second partial derivative is given by

\footnotetext{
${ }^{6}$ See however Dickie, Delorme and Humphreys (1997) for statistical evidence that flexibility of Box-Cox transformations of the dependant variable in hedonic analysis may not be as large as one would like.
} 


$$
\frac{\partial^{2} p_{j}}{\partial c_{k}^{2}}=(1-\lambda) \beta_{k}^{2} p_{j}^{1-2 \lambda}
$$

which implies that as long as $\lambda$ is smaller than 1 , the hedonic function is convex with respect to each characteristic, whatever the sign of $\beta_{k}$.

We estimate (3) by maximum likelihood. ${ }^{7}$ As shown by Dagenais and Dufour (1991) for general non-linear models and Spitzer (1984) for Box-Cox ones, hypothesis-testing by mean of standard Wald criteria (Student tests) or Lagrange multiplier techniques is not invariant to measurement units. Likelihood ratio tests do not suffer from this problem. On the other hand likelihood ratio tests do not lead easily to confidence intervals. We therefore present significancy tests based on the likelihood principle and $95 \%$ confidence interval based on the Student distribution. The later requires a correct computation of the variance covariance matrix of the parameter estimates. In order to do that, we resort to a double length artificial regression (see e.g. Davidson and McKinnon (1993) Chapter 14 pp.492-499 for a thorough explanation of this method).

\subsection{Data}

The estimation of (3) requires micro data on housing prices, housing specific characteristics and amenity characteristics. The relative scarcity of reliable housing data sources in France pushed us to build up our own data set. We limit the study to the sales housing market (rental market is not considered) and to the administrative area of Val d'Oise in the northern part of Paris greater metropolitan area, west of Roissy international airport (see figure 1 in Appendix). In order to obtain reliable information on local public goods we further restrict ourselves to the 33

\footnotetext{
${ }^{7}$ Thorough explanations of estimation method can be found in Hyde (1999).
} 
cities of the Val d'Oise that had at least 10000 inhabitants in the 1990 national census.

This limits the variability in the public goods characteristics. For this reason, we spread the collection of data on individual housing prices in each of these 33 cities on a 9 years period (more precisely 1985-1993). For each city and for every year, data on local public goods, measured at the city level, were obtained from the relevant local public authorities. Data on housing prices were collected from adds taken from free advertising local newspapers. These adds record information on individual prices, the city where the housing is built, as well as on many housingspecific characteristics (e.g. the number of rooms, the presence of a parking lot, an equipped kitchen, etc.). Overall, 8192 observations were collected, allocated between the 33 cities and the 9 years according to the demographic weight of each city in the area.

There are at least three criticisms that one could make to our data set construction.

First, the spreading of the observations over 9 years raises the question of the intertemporal stability of the hedonic price function $h$. We have addressed this issue by introducing time dummies in the list of regressors. The spreading of observations over time raises also some interpretative questions with respect to the relationship between housing's price at some period and the characteristic of the housing at that and subsequent periods. Clearly, the $K$ characteristics of a housing should be distinguished by the time and, if necessary, the state of the world in which they are made available. When buying a dwelling, a household cares about the package of hedonic characteristics provided by the dwelling during the year of purchase but, also, during all subsequent years of existence of the dwelling. Yet, in the empirical specification (3) of the hedonic price function presented above, we explain the price of a particular housing at some year only by the value taken by the considered characteristics at that same year. This way of doing would be adequate if households purchasers were either holding stationary expectations about 
the future quantities of characteristics or holding rational expectations under the additional assumption that housing characteristics are random walks.

Second, one must note that the prices recorded in the data base are advertised - or supply prices. Yet these advertised prices may behave differently from the housing prices at which units of housing were actually traded. Using advertised - rather than transaction - prices would not bias the estimation if the discrepancies between advertized and actual price were independent from the characteristics of the dwelling. Yet, we have no way to empirically verify whether this independence holds. Cheshire and Sheppard (1995) also use supply prices in their hedonic study. They send to the advertisers of their sample a questionnaire three months after the collection of the data to obtain additional information on the actual price at which the dwelling units were sold (if they were). They report a rate of response of some $40 \%$ and, for the houses that happened to be sold during the three months period, an average transaction price that is within a $1 \%$ interval of the average advertized price. Although the housing market considered in Cheshire and Sheppard is somewhat different from that considered here, their results suggest at least that, if it exists at all, the bias associated with the use of advertized price is not excessive. ${ }^{8}$

Third, the city level at which all amenities are measured may be considered inappropriate. As discussed at length in the literature, it would be preferable to measure public good and neighborhood variables at the finest level of observability. Unfortunately, our data set does not allow for performing an analysis at a smaller level than the city one. Information on housing units does not typically mention the neighborhood in which the unit is built. Moreover, many

\footnotetext{
${ }^{8}$ It should also be noticed that advertized prices have one advantage over transaction prices reported to notaries: They are not subject to such understatements as reported transaction prices can be. In France, understatement of transaction prices reported to notaries is common as they enable the parties to reduce their tax payments (in France, housing purchase is taxed at a rate of some $8 \%$ ).
} 
public amenities variables (e.g. tax rates) are only available at the city level. ${ }^{9}$

\subsection{Variables}

The list, description and definition of the 13 dwelling-specific variables and the 17 city specific amenity variables is given in Table 1 in Appendix. Table 2 provides descriptive statistics for the price and variables. We complete this description with a few additional comments on some of the public goods variables.

\section{$<$ Insert Table 2 here $>$}

\subsubsection{Education variables}

As mentioned in introduction, we use two variables to measure the quality of local public schools. The variable Peer is defined as the fraction of the total number of children registered in the three last years of junior high school who are at least two years behind their normal grade level (as determined by their birth rate). Assuming (plausibly given the uniform norms implemented by the French ministry of education) that the pass/failure policy of local school authorities does not exhibit systematic cross-city variations, this indicator measures the fraction of "poorly performing' peers that a given child will interact with on a daily basis in a local public junior high school. It is an institutional particularity of the public school french system which motivates

\footnotetext{
${ }^{9}$ It should moreover be noticed that, in France, the average size of the city is much smaller than in the US (the average city of our sample is only $7,4 \mathrm{Km}^{2}$ ) For this reason, one may expect the inaccuracy of measuring amenities at the city level rather than at the neighborhood one to be less severe in France than there would be in the US.
} 
our choice of the second year of the junior high school as the benchmark year to calculate the fraction of poorly performing peers. As explained by Cousin (1996; p. 60) the second year of junior high school is typically perceived to be the first year where failure is recognized to be a good method for sending to the pupil (or to the parents) a signal that can help in future orientation decisions (choosing a more applied school curriculum for instance). Hence until the first year of junior high school, parents have the right to object to a possible proposal of failure of their child made by the school authorities at the end of the year. Starting from the second year of junior high school, parents loose this opportunity. Interestingly enough, in other regressions not included in this present version, we have considered an alternative specification where the quality of peers is measured by the number of children registered in the first year who are at least two years backward. It turns out that the estimated coefficient of this second indicator of peer group effect (which exhibits only a modest correlation of 0.23 with the variable Peer) presents the wrong sign. It appears, therefore, that it is not the appropriate variable to measure the quality of the peers with whom the pupil interacts.

The second variable is the standard Student/teacher ratio calculated, for each city and year, on all public junior high-schools to which city resident are assigned by the public school zoning system. This variable is obviously a good proxy for the physical input of the human capital production function. One may notice on Table 2 that this variable exhibits very little variation across cities and years due to the egalitarian norms implemented by the french central authorities. The pupil/teacher ratios in junior high schools range from 21.9 to 27.1 , with more than $85 \%$ of the observations lying between 24 and 26.5. It should be noted that Student/teacher is (slightly) negatively correlated with Peer (around 0.25 ) as well as with the variable that measure poverty $(0.41)$ in the city (see below). This suggests that the national public school 
authorities allocate inputs across public schools in a way which partially attempt to compensate the unequal distribution of sociological characteristics across cities.(see also Trancart (1998; p. 49) for more evidence on this).

\subsubsection{Accessibility}

We consider three variables that aim at capturing the accessibility of the city in which the dwelling is located. Two variables, Ptransport and Ctransport, measure the time (in minutes) required to commute from each of the 33 cities to Paris center at morning rush hour using, respectively, public transportation and car transportation. Both variables are computed using information available in $1996 .{ }^{10}$

Both Ptransport and Ctransport are intended to measure the time required to commute from home to work. This rests on the "monocentric" assumption that most inhabitants of Val d'Oise work in the center of Paris. Although this assumption is not strictly true, it is worth keeping in mind that $40 \%$ of the jobs available in the Paris greater metropolitan area are located

\footnotetext{
${ }^{10}$ Commuting time by public transportation is calculated from the various networks of public transportation of the greater Paris metropolitan area (bus, suburban train, RER, and metro) using the official schedule of the public transportation companies (essentially the RATP and the SNCF) for the morning rush hour (7:00-9:00). This commuting time is the shortest that can be achieved when considering all possible combinations of itineraries. It includes the average time taken to commute (by car if necessary) from the various point of the city where the housing is built to the nearest access to the public transport network (train or RER station or bus depot) and the waiting time if any. Destination of commuting is assumed to be the subway and RER station of Chatelet-les Halles in the center of Paris.

Commuting time by car results from simulations performed on the road network of the Paris greater metropolitan area at morning rush hour. Times are computed under the assumption that the driver takes the fastest route to connect the center of the city where he or she lives to Chatelet train station. It also includes the time required to park the car.
} 
in the inner Paris, and that $22 \%$ of the inhabitants of Val d'Oise who work do so in the center of Paris. It should also be noticed that, for historical reasons, the transportation network in France (both public and private) is concentrically organized around the city center of Paris. Many people who commute between two points of the Paris greater metropolitan area must make an interconnection in the city center of Paris. For this reason the commuting time from home to the city center of Paris does capture a significant part of the commuting time of a much larger portion of the Val d'Oise workers than $22 \%$.

One could of course question the use of two distinct variables to capture what is often perceived as a single phenomenon: the time taken to commute from home to work. Such a questioning is legitimate since, in each of the 33 cities covered in our sample, commuting time by public transportation is smaller than commuting time by car. If the time spent in commuting by car and the time spent in commuting by public transportation were perfect substitutes, commuting time by car would not be valued at all by the housing market. Pushed at the limit, if the two commuting times were perfect substitutes, one would not observe any inhabitant of the Val d'Oise on the road network at the morning rush hours! As a matter of facts, the proportion of pure car users among the commuters from the outer ring of the metropolitan area of Paris (to which the Val d'Oise belongs) to Paris is only $19 \%^{11}$. Hence $81 \%$ of these commuters use at least once the public transportation system on some segment of the trip. Nonetheless, the fact that a significant portion of commuters do use the car despite the time difference suggest that the two transportation times are not perfect substitute. For this reason, we have chosen to keep them both in the regression. Keeping constant commuting time by public transportation, one

\footnotetext{
${ }^{11}$ The number comes from "Enquête globale transports", Syndicat des Transports Parisiens, 1997. This figure is different from those presented in the introduction which concern all commuters and not only those ones who from the suburbs commute to Paris.
} 
could therefore expect a priori a positive impact of a marginal reduction of commuting time by car on dwelling prices.

Although commuting from home to work is an important component of the individuals' daily transportation activity, it is not the only one. People also commute to go shopping, to go in vacation, to visit friends and relatives, etc. Not all of these commuting are oriented toward the city center of Paris. To account for other transportation facilities offered by the dwelling localization, we also use as a regressor the distance between the center of the city in which the housing is built and the nearest (in kilometer) freeway entrance (ACmotorway). We interpret this variable as a proxy for the accessibility of the dwelling in terms of overall road transportation. It might be thought that the proximity of a freeway, albeit convenient in terms of transportation facilities, can also be a source of pollution and noise. To account for this, we also introduce among the regressors the number of kilometers of highway that cross the area of the city in which the housing is built relative to the size of the city (Rnuisance). Hence the derivative of the housing price with respect to ACmotorway measures the marginal willingness to pay of the dwelling's owner for improving access to the freeway system, given the density of this highway system in the city where the dwelling is located.

\subsubsection{Environmental variables}

In addition to Rnuisance which would fit naturally in this category, we have introduced the physical distance between the center of the city and Roissy's international airport which bounds the Val d'Oise on the east side. This variable (DistRoissy) captures the (noise) nuisance associated with the geographic proximity of the airport.

Also considered are three variables that are intended to capture the aesthetic characteristics 
of the site on which the dwelling is located. One of this variable (Scenic) measures the length of scenic roads (expressed in meters relative to the area of the city) as recorded on a local Michelin touristic map (under the label "picturesque stretch of road"). ${ }^{12}$ We also have a variable (Elevation) that is defined by the difference between the highest and the lowest point of the city relative to the city's (horizontal) area. Paris' region is rather flat and, for this reason, hills are much appreciated by residents. Finally, the last environmental variable (Green) is the fraction of the city land opened to recreational activities (that is, free from agriculture, road, and building).

The variable Monuments on the other hand, which measures, relative to the city's area, the number of historical buildings belonging to the national heritage, is intended to be a proxy for some aesthetic unmeasured "charm" of the city. Finally, the variable Shopping, defined as the number of detailed shops per 10000 inhabitants, captures the access to commercial facilities.

\subsubsection{Public goods and Taxes}

Two variables gathered under this heading aim at capturing proximity of the dwelling to various intrinsically valuable public equipment (Auditoria, Playgrounds) which are mainly financed by local budgets.

High taxes are the usual counterpart of a generous public good provision even though local taxes are less tightly connected to local public good provision in France than they are in the United States. There are two local taxes paid by households in France: A tax on real estate (taxe sur le foncier bati) (REtax) paid only by the owner of the housing and a so-called dwelling tax (taxe d'habitation) (Dtax) paid by the household who lives in the dwelling (be it as landlord or as

\footnotetext{
${ }^{12}$ The map used is the 1998 edition of the Michelin map no.101 (outskirt of Paris: $1 \mathrm{~cm}=530$ metres).
} 
tenant). ${ }^{13}$ Each of these two taxes is collected by applying a tax rate, chosen by the local public administration, to a dwelling-specific administrative tax base that bears no clear relationship with the dwelling's market value. ${ }^{14}$ Since we do not observe tax liabilities, we proceed by regressing housing on the two tax rates (along with the other housing characteristics). Although not completely pure from a theoretical point of view, this procedure enables us nonetheless to account to some extent for the capitalization of the taxes in the housing value. Furthermore our knowledge of the sample average administrative tax base provides an indirect way of testing the degree of tax capitalization. More specifically, our procedure enable us to check if the estimated hedonic price of either tax rate corresponds to a capitalization of the future taxes liabilities brought about by a marginal increase in the tax rates evaluated at average value of the administrative tax base. Assuming that a purchaser of a unit of housing expects a marginal increases in the current tax rate to remain in effect for ever, this procedure enables us in effect to infer the implicit discount rate used by the household to calculate the present value of its future tax liabilities. This 'revealed' discount rate can then be compared with the discount rate used in the literature to test explicitly for tax capitalization.

\subsubsection{Sociological and neighborhood variables}

The variable Poverty is defined as the fraction of the households living in the city who are exempt from the (national) income tax. This variable is interpreted as a proxy for factors that enter into the production of several public goods supplied by a city and which may be correlated with some of the public goods. The problem with an empirical specification such as (3) below is that it neglects many public goods by putting them in the error term $\varepsilon_{j}$. Yet these omitted

\footnotetext{
${ }^{13}$ A household who owns the housing in which it lives pays both taxes.

${ }^{14}$ See Acosta and Renard (1993, p. 57 and 127) for more details.
} 
characteristics are likely to be correlated with the amenities integrated in the empirical analysis. The reason for this is that many local public goods of a given city (observed and unobserved) are produced by a set of common production factors. An example of factors that enter jointly in the production of several public goods is the distribution of sociological attributes (poverty rate, average income, average level of education, etc.) within the population of a particular city. Typically, one would expect cities with favorable distribution of sociological attributes to exhibit better performance in terms of public safety, school success, quality of the neighborhood, etc. than cities with less favorable distributions of these attributes. The fraction of the households who are free from income tax liabilities is therefore interpreted as summary statistics for the distribution of sociological traits.

We also test a crime variable but it turned out to have no significant impact on housing prices. The weakness of the influence of crime on housing price is common in many hedonic studies (see for instance Lynch and Rasmussen (2001)). It appears therefore that city is not the appropriate level of measurement of criminal acts.

\subsection{Results}

The results obtained from estimating (3) with the independent variables of table 1 are presented in Table 3.

\section{$<$ Insert table 3 here $>$}

The best functional form for the hedonic price function is obtained for $\lambda=-0.1287$. As indicated by the value of the likelihood ratio test, this functional form is significantly different from the linear $(\lambda=1)$ or the log-linear $(\lambda=0)$ form. In accordance with the prediction of the theoretical urban hedonic literature (see e.g. Anderson (1985) and Sheppard (1999)), it implies 
an overall convexity of the hedonic price function with respect to the housing characteristics (in particular, marginal willingness to pay for a given characteristic is increasing with respect to the quantity of this characteristic).

As can be noticed, all housing characteristics behave in an a priori predictable way.

Focusing on public amenities variables, we first notice that, on these 17 variables, 16 are significant at the $1 \%$ confidence level and 1 at the $5 \%$ (student/teacher ratio). All in all, the 25 variables used in our model account for $82 \%$ of the variance of the transformed housing price.

Table 4 gives the empirical estimates of hedonic prices for the urban amenities. ${ }^{15}$ They correspond to the partial derivative of the hedonic price function in the case of continuous variables, and to the discrete price difference in the case of discrete variables at the average housing of the sample. Table 4 also gives, for all variables expressed in continuous units, the absolute value of the "hedonic elasticity" of the amenity measured at the average housing (the percentage variation in housing price brought about by a one percent variation in the amenity).

\section{$<$ Insert table 4 here $>$}

For school variables, one notices that both are significant. The estimated marginal willingness to pay for reducing by one point the fraction of poorly performing peers at school is $255 €$ (or $1417 €$ per point of standard deviation). Reducing class size by one pupil is valued $854 €$ by the owner of the average housing of our sample (or $785 \in$ per point of standard deviation) . Summing these two effects, we obtain that the owner of the average housing is willing to pay some $2200 €$ for reducing by one point of standard deviation the two indicators of school quality considered herein. This should be compared with the marginal willingness to pay of $3948 \$$ for a 1 point of standard deviation amelioration in test score at primary schools obtained by

\footnotetext{
${ }^{15}$ Hedonic prices for private characteristics can be provided upon request.
} 
Black (1999) in wealthy suburbs of Boston. We should mention also that, when interpreted in a human capital perspective, these figures suggest that the impact of poorly performing peers and/or student/teacher ratio on the (future) human capital of the child is modest. Take for instance the $1417 \in$ that the owner of the average household is willing to pay for reducing by one point of standard deviation the fraction of poorly performing peers that its child will encounter at public high schools. Assuming that this amount corresponds to the actualization at a discount rate of $3.5 \%$ of future earning losses brought about by such an exposure to "bad peers" and that the active life starts at 25 and ends at 65 , such a hedonic price is consistent with a yearly earning loss of... $65.3 €$.

Transportation variables provide interesting results. Reducing either car or public transportation time by one minute increases housing price. The value of reducing by one minute the time taken to reach the city center of Paris is higher for public transportation than car (345 $€$ by public transportation, $276 €$ by car) but the difference is not statistically significant. An interesting exercise is to estimate the value of an elementary unit of time revealed by the hedonic price of Ptransport. Assuming that an average working individual will commute 230 days per year forever, and using a discount rate of $3.5 \%$, the hedonic price of $345 €$ associated with a one minute reduction in commuting time is consistent with a value of the minute of some 5 cents $(3$ $€$ for an hour). This figure, which is about half the net French minimum wage rate, suggests either that the discount rate used is too low or that individuals tend to consider that commuting time has less disutility than the time spent to work. The convexity of the hedonic price function entails that the marginal willingness to pay is decreasing at a decreasing rate, which is consistent with the predictions of classical models of the monocentric city. If the generalized transportation cost (pecuniary and time cost) is linear or concave with respect to the distance to 
the central business district (CBD), then the equilibrium market rent curves are strictly convex with respect to the distance to the CBD (see e.g. Fujita (1999 p. 57)). This interpretation must of course be taken with a grain of salt since the convexity observed here concerns to the commuting time, while the prediction of the theory is about the physical distance.

Another interesting result is the significant hedonic price of 857 euros attached to a one kilometer reduction in the distance from the nearest freeway entrance (given the density of the highway network in the city where the dwelling is built). The significant hedonic price of 1881 euros attached to a kilometer reduction in the density of this network (given the distance from the nearest freeway entrance) is even more interesting. It reveals that the nuisance created by highway (given access) is more important (in absolute value) than the benefit which results from improving access (given nuisance).

Living one kilometer away from Roissy airport increases the value of the average housing by some 275 euros.

The four environmental and geographical variables Scenic, Elevation, Green, and Monuments are significant but their contribution to price seems rather modest. ${ }^{16}$

The hedonic price of adding one auditorium in the (virtual) city in which the average dwelling is built (4105 euros, roughly $4 \%$ of the price of the average housing) might look high at first glance. It is difficult to believe that it is the representative dwelling purchaser's intrinsic preference for music, theatres, etc. which accounts for a willingness to pay of 4105 euros just to live

\footnotetext{
${ }^{16}$ For these variables, we compute the hedonic price associated with an increase of the numerator of the variable equal to one unit (with the exception of Elevation for which we consider an increase of the numerator equal to 10 meters). So we have the hedonic price of one more kilometer of scenic roads in the (virtual) city in which the average dwelling is built (or the hedonic price of one more hectar of green space or of an additional monument). We use the same method of computation for the variables Auditoria and Playgrounds.
} 
in a city which possesses one more show room than the average city. A possible explanation is that the fact for a city to have or not an auditorium is a proxy for other unmeasured amenities. This explanation finds some support in the fact that more than one half of the cities covered by our sample (precisely, 19 out of 33) do not have any auditorium.

An interesting result is the strong capitalization effect of local tax rates. For increasing by one point the dwelling tax rate (resp. the real estate tax rate) leads to a reduction of 773 euros (resp. 718 euros) in the value of the average housing unit. In terms of the earlier discussion, if we apply the tax rates on a unit of housing of average administrative value, and under the assumption that a one point increase in the tax rate is expected by the household to last forever, our average estimate of the negative capitalization of 773 euros (resp. 718) reveals a discount rate of $3.7 \%$ (resp. $3.2 \%$ ). The difference between the two rates is not statistically significant. These figures fall down a plausible confidence interval of the actual real interest rates on mortgage loans observed for that period; In terms of Palmon and Smith's (1998) methodology, these results indicate a full capitalization of taxes at a real discount rate of $3.5 \%$. They suggest the existence of an almost complete "Laffer effect". If tax authorities were to base their local tax rate on the market (rather than administrative) value of the housing, then increasing tax rates would have virtually no effect on the expected future government tax revenues.

\section{Policy implications of the results}

In this section, we show how, under specific assumptions, hedonic prices of public goods provide exact measures of their social marginal values and we use our hedonic estimates to evaluate some public programs aimed at reducing school failure in poor cities. We first recall the condition under which the sum of hedonic prices for a public good taken over the inhabitants of a particular city 
provides an exact measure of the social value attached by the population of the city for a small improvement in the available quantity of this public good.

Assume that there are $H$ households who make the same decision as that of the representative household examined in section 2 (indexing by $i \in\{1, \ldots, H\}$ their utility functions and consumption sets and denoting by $\widehat{y}_{i}$ the wealth of household $i$ ). All these households face the same hedonic price function $h($.$) . Since every household's optimal choice of characteristics$ package depends upon wealth only (given $h(\cdot))$, we define household $i$ 's indirect utility function $V_{i}: \mathbb{R}_{+} \rightarrow \mathbb{R}_{+}$with image $v_{i}$ by

$$
\begin{gathered}
V_{i}\left(\widehat{y}_{i}\right)=\max _{(\mathbf{c}, x)} U_{i}(\mathbf{c}, x) \\
\text { subject to } x+h(\mathbf{c}) \leq \widehat{y}_{i} \text { and }(\mathbf{c}, x) \in \mathbf{X}
\end{gathered}
$$

Assume now that the distribution of incomes across households is considered optimal with respect to the social evaluation function $S: \mathbb{R}_{+}^{H} \rightarrow \mathbb{R}_{+}$defined by

$$
S\left(y_{1}, \ldots, y_{H}\right)=W\left(V_{1}\left(y_{1}\right), \ldots, V_{N}\left(y_{H}\right)\right)
$$

where $W: \mathbb{R}_{+}^{H} \rightarrow \mathbb{R}_{+}$is a continuously differentiable and increasingly monotonic BergsonSamuelson social welfare function. This assumption amounts to asserting that observed $\left(\widehat{y}_{1}, \ldots, \widehat{y}_{H}\right)$ are (interior) solutions of the following program

$$
\max _{y_{1}, \ldots, y_{H}} S\left(y_{1}, \ldots, y_{H}\right) \text { subject to } \sum_{i=1}^{H} y_{i} \leq \sum_{i=1}^{H} \widehat{y}_{i}
$$

and, therefore, satisfy first order conditions

$$
\frac{\partial W\left(V_{1}\left(\widehat{y}_{1}\right), \ldots, V_{N}\left(\widehat{y}_{H}\right)\right)}{\partial v_{i}} \frac{\partial V_{i}\left(\widehat{y}_{i}\right)}{\partial y_{i}}=\frac{\partial W\left(V_{1}\left(\widehat{y}_{1}\right), \ldots, V_{N}\left(\widehat{y}_{H}\right)\right)}{\partial v_{l}} \frac{\partial V_{i}\left(\widehat{y}_{l}\right)}{\partial y_{l}}=\lambda
$$

for every household $i$ and $l$ where $\lambda$ is some real non-negative constant (the Lagrange-KuhnTucker multiplier associated to the constraint in the program $(\mathrm{P}))$. 
Assume that we want to evaluate the social value of a "small" project consisting in an increment of $d c_{k}$ in the quantity of the amenity $k$ in some city $j$. Letting $H^{j}$ denoting the number of households who optimally choose to locate in city $j$, the social value $\Delta W$ of such a project at households's initial optimal choice is approximated by

$$
\Delta W=\sum_{i=1}^{H^{j}} \frac{\partial W\left(V_{1}\left(\widehat{y}_{1}\right), \ldots, V_{N}\left(\widehat{y}_{N}\right)\right)}{\partial v_{i}} \frac{\partial U_{i}\left(\mathbf{c}_{i}^{*}, x_{i}^{*}\right)}{\partial c_{k}} d c_{k}
$$

From the first order conditions of households maximization programs, this can be written as

$$
\Delta W=\sum_{i=1}^{H^{j}} \frac{\partial W\left(V_{1}\left(\widehat{y}_{1}\right), \ldots, V_{N}\left(\widehat{y}_{N}\right)\right)}{\partial v_{i}} \frac{\partial V i\left(\widehat{y}_{i}\right)}{\partial y_{i}} \frac{\left.\partial h\left(\mathbf{c}_{i}^{*}, x_{i}^{*}\right)\right)}{\partial c_{k}} d c_{k}
$$

which, given the optimality of income distribution and ordinality of social welfare measurement, amounts to

$$
\Delta W=\sum_{i=1}^{H^{j}} \frac{\left.\partial h\left(\mathbf{c}_{i}^{*}, x_{i}^{*}\right)\right)}{\partial c_{k}} d c_{k}
$$

In a continuous context with optimal distribution of incomes therefore, summing the implicit marginal prices of local public goods produced by a "small" project over all occupied housings built in the location where the project is implemented provides an exact measure of the social value of the project. It is worth emphasizing the strength of the condition that observed households incomes are optimally distributed with respect to the same social welfare function as that used to appraise the value of public projects. This condition amounts to using in project evaluation the same ethics as that who considers the actual income distribution to be "just" (or socially optimal). This particular ethic may not command widespread support.

\section{$<$ Insert table 5 about here $>$}

Given this proviso, we can apply this formula and compute the social benefit that a reduction of one unit in some local public good could bring about in the cities. We do this in table 5 for the 
variable Peer in a few poor cities of Val d'Oise in which the French Ministry of the city affairs has launched a large expenditure program. Column 3 in table 5, evaluates the sum of marginal willingness to pay for a one point reduction in peers taken over all landlords of every concerned city. These benefits, although significant, underestimate the total benefits that the inhabitants of the city would obtain out of the policy since they take no account of households who do not own their housing. ${ }^{17}$ These figures can be compared with the government capital spending in these cities for local public schools that appear in column 4. It is of course difficult to appraise these figures without further information on the technology used by the government to convert public fund into reduction of behind grade levelness at school. However, and unless we assume an extremely high rate of conversion of government money into reduction of school failure, we must recognize that government spending is very modest in most of the cities with respect to our estimation of the benefits aimed. Column 5 and 6 make the same kind of comparison in annual terms using the discounted rate revealed by the capitalization of tax rate in our empirical model. Here again, government spending seems modest relative to our estimation of the benefits.

\section{Conclusion}

This study reveals a few noticeable facts. In Paris metropolitan area, dwelling prices appear to be sensitive to both public and car transportation. At a discount rate of 3.5\%, the willingness to pay of the owner of the average housing of our sample for reducing marginally her commuting time to work is consistent with an hourly value of this owner's time of some 3 euros, a figure

\footnotetext{
${ }^{17}$ On the other hand, it is worth recalling that housing prices used in this study are supply prices and not transaction prices. It is also probably worth recalling that these figures are obtained from the sale (rather than the renting) market. These two states of affairs suggest an overestimation of the marginal willingness to pay.
} 
that is much lower than the value of the minimum wage for the reference years. The second important results revealed by our study is the clear capitalization of local taxes. Furthermore, our empirical results support the view that the quality of local public schools affects significantly housing price. It appears that both objective inputs and peer group effects affects significantly house price when control is made for other neighborhood variables such as the poverty rate. The importance of the estimates of the social marginal value of avoidance of bad peer is worth stressing. In an average city counting 25000 landlords, a policy leading to a reduction of one percent in the number of children who fail at school has a social marginal value of some 6.375 million of euros.

\section{Acknowledgements}

We gratefully acknowledge the financial support from the "Direction Générale de l'équipement du Val d'Oise" as well as from the program "Action concertée incitative Villes" of the Ministère de l'enseignement supérieur et de la recherche. We thank also Stéphane Bujeau and JeanFrançois Guillaume for their competent research assistance, André de Palma and Cedric Fontan for providing us the data about transportation time costs and Richard Arnott and Nancy Wallace for helpful comments and Fabrice Barthélémy for a thorough discussion about DLR.

\section{References}

Acosta, R. and Renard, V. (1993) "Urban Land and Property Markets in France", UCL Press.

Anderson, J.E. (1985) "On testing the convexity of the hedonic price function", Journal of Urban Economics, 18, p.334-337.

Arnott R. and Rowse, J. (1987) "Peer Group Effects and Educational Attainment", Journal of Public Economics, 32, p.287-305. 
Bartik, T.J. (1987) "The Estimation of Demand Parameters in Hedonic Prices Models", Journal of Political Economy, 95, p.81-88.

Black, S.E. (1999) "Do Better Schools Matter? Parental Valuation of Elementary Education", Quarterly Journal of Economics, 114, p.578-599.

Bogart, W.T. and B.A Cromwell (2000), "How much is a good school worth", National Tax Journal, 47, p.280-305.

Box, G.E.P. and Cox, D.R. (1964) "An Analysis of Transformations", Journal of the Royal Statistical Society, ser. B, p. 211-252.

Cheshire, P. and Sheppard, S. (1995) "On the Price of Land and the Value of Amenities", Economica, 62, p. 247-267.

Cousin, O. (1996) "Construction et Evaluation de l'Effet Etablissement", Revue Française de Pédagogie, 115, p. 59-75.

Cropper, M.L., Deck, B.L. and McConnell, K.E. (1988) "On the Choice of Functionnal Form for Hedonic Price Function", Review of Economics and Statistics, 70, p. 668-675.

Dagenais, M.G. and Dufour, J.M. (1991) "Invariance, Nonlinear Models, and Asymptotic Tests", Econometrica, 59, p. 1601-1615.

Davidson, R. and McKinnon, J.G. (1993) "Estimation and Inference in Econometrics", NewYork, Oxford University Press.

Dickie, M., Delorme, J. R. and Humfrey, J. M. (1997) "Hedonic prices, good-specific effects and functional form: Inferences from cross-section time series data", Applied Economics, 29, 239-249. 
Ekeland, I., Heckman, J.J. and Nesheim, L. (2004) "Identification and Estimation of Hedonic Models", Journal of Political Economy, 112, p. 60-109.

Ellikson, B. (1979) "Competitive Equilibrium with Local Public Goods", Journal of Economic Theory, 21, p. 46-61.

Fujita M.(1999) "Urban Economic Theory, Land Use and City Size", Cambridge University Press, Cambridge, paperback reprint.

Ginsburgh, V. and Waelbroeck, P. (1998) "The EC and Real Estate Rentes in Brussels", Regional Science and Urban Economics, 28, p. 497-511.

Hanushek, E.A. (1986) "The Economics of Schooling: Production and Efficiency in Public Schools", Journal of Economic Literature, 24, p. 1141-1177.

Hyde, S.K. (1999) "Likelihood Based Inference on the Box-Cox Family of Transformations: SAS and Matlab Programs", Technical Report, Mathematical Sciences, Montana State University.

Kanemoto, Y. (1988) "Hedonic Prices and the Benefit of Public Projects", Econometrica, 56, p.981-989.

Kiel, A.K and McClain, K.T. (1996) "House Price Recovery and Stigma after a Failed Siting", Applied Economics, 28, 1351-1358.

Lynch, A.K. and Rasmussen, D.W. (2001) "Measuring the Impact of Crime on House Prices", Applied Economics, 33, p.1981-1989.

Mas-Colell, A. (1975) "A Welfare Analysis of Equilibrium with Differentiated Commodities", Journal of Mathematical Economics, 2, p. 263-295. 
Palmon, O. and Smith, B.A. (1998) "A New Approach for Identifying the Parameters of a Tax Capitalization Model", Journal of Urban Economics, 44, p. 299-316.

Rasmussen, D.W. and Zuehlke, T. W. (1990) "On the Choice of Functional Form for Hedonic Price Functions", Applied Economics, 22, p. 431-438.

Rosen, S. (1974) "Hedonic Prices and Implicit Markets: Product Differentiation in Pure Competition", Journal of Political Economy, 82, p. 34-55.

Scotchmer, S. (1985) "Hedonic Prices and Cost/Benefit Analysis", Journal of Economic Theory, 37, p.55-75.

Scotchmer, S. (1986) "The Short Run and the Long Run Benefits of Environmental Improvements", Journal of Public Economics, 30, p.61-81.

Sheppard, S. (1999) "Hedonic Analysis of Housing Markets", in Cheshire, P. and Mills, E., eds., Handbook of Regional and Urban Economics, vol. 3. North-Holland, New York.

Spitzer, J. J. (1984) "Variance Estimates in Models with the Box-Cox Transformation: Implications for Estimation and Hypothesis Testing", Review of Economics and Statistics, 66, p. $645-652$.

Trancart, D.(1998) "L'Evolution des Disparités entre Colléges Publics", Revue Française de Pédagogie, 124, p. 43-53.

\title{
6 Appendix
}

\author{
$<$ Insert figure 1 about here $>$ \\ $<$ Insert table 1 about here $>$
}




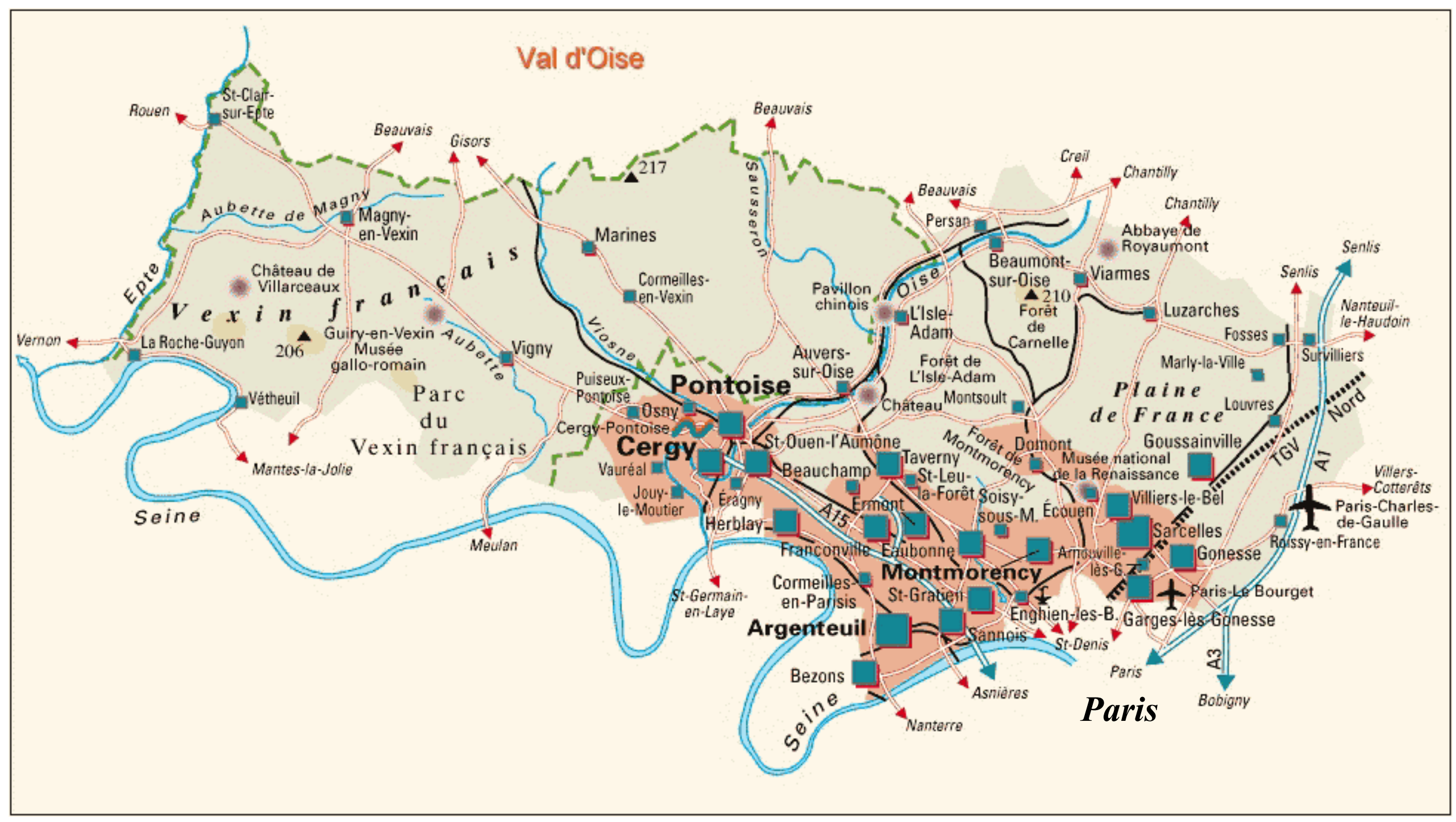

Figure 1: Map of Val d'Oise 
Table 1: Variable Description

\begin{tabular}{|c|c|c|c|}
\hline \multicolumn{4}{|c|}{ A) Private variables } \\
\hline Variable Name & Definition & Unit of measurement & Source \\
\hline Price & $\begin{array}{l}\text { price of the housing } \\
\text { divided by a price index }\end{array}$ & continuous (euros) & free newspapers adds \\
\hline Second room & $\begin{array}{l}\text { whether or not the housing } \\
\text { has a second room }\end{array}$ & dummy & free newspapers adds \\
\hline Third room & $\begin{array}{l}\text { whether or not the housing } \\
\text { has a third room }\end{array}$ & dummy & free newspapers adds \\
\hline Fourth room & $\begin{array}{l}\text { whether or not the housing } \\
\text { has a fourth room }\end{array}$ & dummy & free newspapers adds \\
\hline Fifth room & $\begin{array}{l}\text { whether or not the housing } \\
\text { has a fifth room }\end{array}$ & dummy & free newspapers adds \\
\hline Sixth room & $\begin{array}{l}\text { whether or not the housing } \\
\text { has a sixth room }\end{array}$ & dummy & free newspapers adds \\
\hline Another room & number of rooms above 6 & discrete & free newspapers adds \\
\hline Balcony & $\begin{array}{l}\text { whether or not the housing } \\
\text { has a balcony }\end{array}$ & dummy & free newspapers adds \\
\hline Kitchen & $\begin{array}{l}\text { whether or not the housing } \\
\text { has an equipped kitchen }\end{array}$ & dummy & free newspapers adds \\
\hline Parking & $\begin{array}{l}\text { whether or not the housing } \\
\text { has a parking }\end{array}$ & dummy & free newspapers adds \\
\hline House & $\begin{array}{l}\text { whether or not the housing } \\
\text { is a house or an apartment } \\
\text { in a collective building }\end{array}$ & dummy & free newspapers adds \\
\hline Basement & $\begin{array}{l}\text { whether or not the housing } \\
\text { has a basement }\end{array}$ & dummy & free newspapers adds \\
\hline Garden & $\begin{array}{l}\text { whether or not the housing } \\
\text { has a garden }\end{array}$ & dummy & \begin{tabular}{|l} 
free newspapers adds \\
\end{tabular} \\
\hline Garden size & size of the garden & continuous $\left(\mathrm{m}^{2}\right)$ & free newspapers adds \\
\hline
\end{tabular}

\begin{tabular}{|l|l|l|l|}
\hline Variable Name & Definition & Unit of measurement & Source \\
\hline Peer & $\begin{array}{l}\text { fraction of the high school } \\
\text { pupils who are at least two } \\
\text { years backward in the } \\
\text { three last years of high } \\
\text { school }\end{array}$ & $\begin{array}{l}\text { percent (average over } \\
\text { the public schools in the } \\
\text { city) }\end{array}$ & Ministry of education \\
\hline Pupils/teacher & $\begin{array}{l}\text { average number of pupils } \\
\text { per class in public high } \\
\text { schools }\end{array}$ & $\begin{array}{l}\text { percent (average over } \\
\text { the public schools in the } \\
\text { city) }\end{array}$ & Ministry of education \\
\hline
\end{tabular}


B) Accessibility

\begin{tabular}{|l|l|l|l|}
\hline Variable Name & Definition & Unit of measurement & Source \\
\hline Ptransport & $\begin{array}{l}\text { time taken by public } \\
\text { transportation to commute } \\
\text { between the city center } \\
\text { and center of Paris in } \\
\text { the morning rush hour }\end{array}$ & Minutes & I.A.U.R.I.F (96) \\
\hline Ctransport & $\begin{array}{l}\text { time taken to commute by } \\
\text { car between the city and } \\
\text { the center of Paris in the } \\
\text { morning rush hour }\end{array}$ & Minutes & I.A.U.R.I.F (96) \\
\hline ACmotorway & $\begin{array}{l}\text { distance between the city } \\
\text { center and the nearest } \\
\text { freeway entrance }\end{array}$ & Km & authors \\
\hline
\end{tabular}

C) Environmental and geographic variables

\begin{tabular}{|l|l|l|l|}
\hline Variable Name & Definition & Unit of measurement & Source \\
\hline DistRoissy & $\begin{array}{l}\text { distance between the city } \\
\text { and Roissy airport }\end{array}$ & $\begin{array}{l}\text { km } \\
\text { authors }\end{array}$ \\
\hline Rnuisance & $\begin{array}{l}\text { lenght of the highway } \\
\text { network relative to the city } \\
\text { territory }\end{array}$ & $\mathrm{km} / \mathrm{km}$ squared & $\begin{array}{l}\text { computation by the } \\
\text { authors }\end{array}$ \\
\hline Scenic & $\begin{array}{l}\text { lenght of scenic roads } \\
\text { relative to the area of the } \\
\text { city }\end{array}$ & $\mathrm{km} / \mathrm{km}$ squared & $\begin{array}{l}\text { Michelin's map, ed.1998, } \\
\text { n.101 }\end{array}$ \\
\hline Elevation & $\begin{array}{l}\text { difference between the } \\
\text { highest and the lowest } \\
\text { point in the city relative to } \\
\text { the area of the city }\end{array}$ & $\begin{array}{l}\text { m/m squared } \\
\text { hectares of the city land } \\
\text { open to public as natural } \\
\text { space relative to the area } \\
\text { of the city }\end{array}$ & percent \\
\hline Green & $\begin{array}{l}\text { Number of historical } \\
\text { buildings per km squared }\end{array}$ & continous & $\begin{array}{l}\text { anventaire des terrains } \\
\text { ouverts au public, Val } \\
\text { d'Oise by } \\
\text { I.A.U.R.I.F 1990 }\end{array}$ \\
\hline Monuments & $\begin{array}{l}\text { number of salaried } \\
\text { workers in retail stores per } \\
10000 \text { inhabitants }\end{array}$ & $\begin{array}{l}\text { Inventaire Continous } \\
\text { INSEE 1998 }\end{array}$ \\
\hline Shopping & & $\begin{array}{l}\text { Unemployment Insurance } \\
\text { office of the Paris } \\
\text { Metropolitan Area }\end{array}$ \\
\hline
\end{tabular}

E) Public goods and taxes

\begin{tabular}{|l|l|l|l|}
\hline Variable Name & Definition & Unit of measurement & Source \\
\hline Auditoria & $\begin{array}{l}\text { number of auditoria per } \\
10000 \text { inhabitants }\end{array}$ & continous & $\begin{array}{l}\text { National census (1981 and } \\
1990)\end{array}$ \\
\hline Playgrounds & $\begin{array}{l}\text { number of playgrounds } \\
\text { per 10000 inhabitants }\end{array}$ & continous & $\begin{array}{l}\text { National census (1981 and } \\
1990)\end{array}$ \\
\hline REtax & $\begin{array}{l}\text { rate of the tax on real } \\
\text { estate }\end{array}$ & $\begin{array}{l}\text { percent of the } \\
\text { administrative value of } \\
\text { the housing }\end{array}$ & Tax authorities \\
\hline Dtax & rate of the dwelling tax & $\begin{array}{l}\text { percent of the the } \\
\text { administrative value of } \\
\text { the housing }\end{array}$ & Tax authorities \\
\hline
\end{tabular}

G) Sociological and neighborhood variables

\begin{tabular}{|l|l|l|l|}
\hline Variable Name & Definition & Unit of measurement & Source \\
\hline Poverty & $\begin{array}{l}\text { fraction of households } \\
\text { who do not pay income } \\
\text { taxes }\end{array}$ & percent & Tax authorities \\
\hline
\end{tabular}


Table 2: Summary statistics for the variables

\begin{tabular}{|c|c|c|c|c|}
\hline Variable & Mean & $\begin{array}{l}\text { Standard } \\
\text { deviation }\end{array}$ & Minimum & Maximum \\
\hline House's price & 112380.40 & 64795.62 & 12195.92 & 666202.20 \\
\hline Second room & 0.964 & 0.185 & 0 & 1 \\
\hline Third room & 0.885 & 0.318 & 0 & 1 \\
\hline Fourth room & 0.682 & 0.465 & 0 & 1 \\
\hline Fifth room & 0.396 & 0.489 & 0 & 1 \\
\hline Sixth room & 0.163 & 0.369 & 0 & 1 \\
\hline Another room & 0.084 & 0.412 & 0 & 6 \\
\hline Equipped kitchen & 0.337 & 0.472 & 0 & 1 \\
\hline Parking & 0.656 & 0.474 & 0 & 1 \\
\hline Balcony & 0.274 & 0.446 & 0 & 1 \\
\hline House & 0.555 & 0.496 & 0 & 1 \\
\hline Basement & 0.580 & 0.493 & 0 & 1 \\
\hline Garden & 0.384 & 0.486 & 0 & 1 \\
\hline Garden size & 186.49 & 320.79 & 0 & 5700 \\
\hline Peer & 17.99 & 5.55 & 6.37 & 36.47 \\
\hline Student/teacher & 25.15 & 0.909 & 21.94 & 27.11 \\
\hline Ptransport & 45.86 & 10.56 & 31 & 76 \\
\hline Ctransport & 96.42 & 9.76 & 79 & 124 \\
\hline Acmotorway & 3.430 & 2.78 & 0.885 & 13 \\
\hline Rnuisance & 0.259 & 0.211 & 0 & 0.721 \\
\hline DistRoissy & 26.74 & 10.11 & 6 & 45 \\
\hline Scenic & 0.082 & 0.109 & 0 & 0.381 \\
\hline Elevation & 0.103 & 0.085 & 0 & 0.304 \\
\hline Green & 9.07 & 11.83 & 0.078 & 57.11 \\
\hline Monuments & 0.210 & 0.429 & 0 & 2.37 \\
\hline Shopping & 66.78 & 42.57 & 14.55 & 282.79 \\
\hline Auditoria & 0.288 & 0.395 & 0 & 1.45 \\
\hline Playgrounds & 0.841 & 0.774 & 0 & 3.88 \\
\hline Retax & 15.15 & 4.87 & 6.49 & 28.22 \\
\hline Dtax & 12.15 & 2.45 & 6.41 & 19.3 \\
\hline Poverty & 33.67 & 6.91 & 20.7 & 55.24 \\
\hline Year1986 & 0.102 & 0.303 & 0 & 1 \\
\hline Year1987 & 0.117 & 0.321 & 0 & 1 \\
\hline Year1988 & 0.110 & 0.313 & 0 & 1 \\
\hline Year1989 & 0.116 & 0.321 & 0 & 1 \\
\hline Year1990 & 0.126 & 0.332 & 0 & 1 \\
\hline Year1991 & 0.110 & 0.313 & 0 & 1 \\
\hline Year1992 & 0.100 & 0.301 & 0 & 1 \\
\hline Year1993 & 0.106 & 0.308 & 0 & 1 \\
\hline
\end{tabular}


Table 3: Estimation Results

\begin{tabular}{|c|c|c|c|c|}
\hline Variable & Coef. & Std. Err. & \multicolumn{2}{|c|}{ 95\% Conf. Interval } \\
\hline Lambda & $-0.128^{* *}$ & 0.011 & -0.151 & -0.106 \\
\hline $\mathrm{C}$ & $5.917^{* *}$ & 0.310 & 5.307 & 6.526 \\
\hline Second room & $0.066^{* *}$ & 0.009 & 0.048 & 0.085 \\
\hline Third room & $0.049^{* *}$ & 0.007 & 0.036 & 0.063 \\
\hline Fourth room & $0.034^{* *}$ & 0.005 & 0.024 & 0.044 \\
\hline Fifth room & $0.034^{* *}$ & 0.005 & 0.024 & 0.044 \\
\hline Sixth room & $0.032^{* *}$ & 0.005 & 0.022 & 0.043 \\
\hline Another room & $0.023^{* *}$ & 0.003 & 0.016 & 0.031 \\
\hline Equipped kitchen & $0.017^{* *}$ & 0.002 & 0.012 & 0.023 \\
\hline Parking & $0.017^{* *}$ & 0.002 & 0.011 & 0.022 \\
\hline Balcony & $0.011^{* *}$ & 0.002 & 0.007 & 0.016 \\
\hline House & $0.043^{* *}$ & 0.006 & 0.031 & 0.055 \\
\hline Basement & $0.004^{* *}$ & 0.001 & 0.001 & 0.007 \\
\hline Garden & $0.006^{* *}$ & 0.002 & 0.002 & 0.010 \\
\hline Garden size & $0.00006^{* *}$ & 0.00001 & 0.00004 & 0.00008 \\
\hline Peer & $-0.0005^{\star *}$ & 0.0002 & -0.0009 & -0.0002 \\
\hline Student/teacher & $-0.002^{*}$ & 0.0008 & -0.003 & -0.0003 \\
\hline Ptransport & $-0.0008^{* *}$ & 0.0001 & -0.001 & -0.0004 \\
\hline Ctransport & $-0.0006^{* *}$ & 0.0002 & -0.001 & -0.0002 \\
\hline Acmotorway & $-0.002^{* *}$ & 0.0004 & -0.002 & -0.001 \\
\hline Rnuisance & $-0.032^{* *}$ & 0.005 & -0.043 & -0.020 \\
\hline DistRoissy & $0.0006^{* *}$ & 0.0001 & 0.0003 & 0.0009 \\
\hline Scenic & $0.029^{\star *}$ & 0.009 & 0.010 & 0.048 \\
\hline Elevation & $0.039^{* *}$ & 0.011 & 0.016 & 0.062 \\
\hline Green & $0.0002^{* *}$ & 0.00009 & 0.00004 & 0.0004 \\
\hline Monuments & $0.008^{* *}$ & 0.002 & 0.004 & 0.012 \\
\hline Shopping & $0.0001^{* *}$ & 0.00002 & 0.00008 & 0.0001 \\
\hline Auditoria & $0.023^{* *}$ & 0.003 & 0.015 & 0.031 \\
\hline Playgrounds & $0.004^{* *}$ & 0.001 & 0.002 & 0.006 \\
\hline Retax & $-0.001^{* *}$ & 0.0003 & -0.002 & -0.001 \\
\hline Dtax & $-0.001^{* *}$ & 0.0004 & -0.002 & -0.0009 \\
\hline Poverty & $-0.001^{* *}$ & 0.0002 & -0.002 & -0.001 \\
\hline Year1986 & $0.025^{* *}$ & 0.004 & 0.017 & 0.034 \\
\hline Year1987 & $0.050^{* *}$ & 0.007 & 0.035 & 0.064 \\
\hline Year1988 & $0.075^{\star \star}$ & 0.010 & 0.054 & 0.096 \\
\hline Year1989 & $0.108^{* *}$ & 0.015 & 0.078 & 0.138 \\
\hline Year1990 & $0.136^{\star *}$ & 0.019 & 0.099 & 0.174 \\
\hline Year1991 & $0.148^{\star \star}$ & 0.020 & 0.107 & 0.189 \\
\hline Year1992 & $0.146^{* *}$ & 0.020 & 0.106 & 0.186 \\
\hline Year1993 & $0.138^{* *}$ & 0.019 & 0.100 & 0.176 \\
\hline Number of observations & & 8192 & & \\
\hline Log likelihood & & -93428.6 & & \\
\hline
\end{tabular}

\begin{tabular}{lrrr}
\hline Test $\mathbf{H}_{\mathbf{0}}$ & Restricted $\mathbf{l g} \boldsymbol{L}$ & $\boldsymbol{\chi}^{\mathbf{2}(\mathbf{1})}$ & Pr> $\boldsymbol{\chi}^{\mathbf{2}}$ \\
Lambda $=-1$ & -99565.396 & 5513.25 & 0.000 \\
Lambda $=0$ & -93491.246 & 125.31 & 0.000 \\
Lambda $=1$ & -97670.453 & 8483.73 & 0.000 \\
\hline
\end{tabular}

** Coefficient significantly different from zero at the 0.01 level

* Coefficient significantly different from zero at the 0.05 level 
Table 4: Hedonic Price of Urban Amenities

\begin{tabular}{lcc}
\hline Variable name & $\begin{array}{c}\text { Hedonic price } \\
\text { (Euros) }\end{array}$ & $\begin{array}{c}\text { Elasticity } \\
\text { (\%) }\end{array}$ \\
\hline Peer & 255 & 0.0659 \\
Student/teacher & 854 & 0.2212 \\
Ptransport & 345 & 0.1631 \\
Ctransport & 276 & 0.2744 \\
Acmotorway & 857 & 0.0302 \\
Rnuisance & 1881 & 0.0050 \\
DistRoissy & 275 & 0.0756 \\
Scenic & 168 & 0.0001 \\
Elevation & 225 & 0.0002 \\
Green & 98 & 0.0091 \\
Monuments & 482 & 0.001 \\
Shopping & 59 & 0.0404 \\
Auditoria & 4105 & 0.0121 \\
Playgrounds & 733 & 0.0063 \\
REtax & 718 & 0.1119 \\
Dtax & 773 & 0.0967 \\
Poverty & 670 & 0.2322 \\
\hline
\end{tabular}


Table 5: Cost-Benefit Comparisons of Public Spending for Reducing School Failure

\begin{tabular}{|c|c|c|c|c|c|c|}
\hline & (1) & (2) & (3) & (4) & $(5)$ & (6) \\
\hline & $\begin{array}{l}\text { \% of owners } \\
1990 \text { census }\end{array}$ & $\begin{array}{c}\text { Number of } \\
\text { housing units } \\
1990 \text { census }\end{array}$ & \begin{tabular}{|c|} 
Total benefit of a \\
permanent reduction of \\
school failure by 1 \\
point (in thousand of \\
euros)
\end{tabular} & $\begin{array}{l}\text { Total public spending } \\
\text { including capital } \\
\text { expenditures } 1993 \text { (in } \\
\text { thousand of euros) }\end{array}$ & $\begin{array}{l}\text { Annual benefit of a } \\
\text { reduction of school } \\
\text { failure by } 1 \text { point (in } \\
\text { thousand of euros) }\end{array}$ & $\begin{array}{c}\text { Public spending } \\
\text { excluding capital } \\
\text { expenditure } 1993 \text { (in } \\
\text { thousand of euros) }\end{array}$ \\
\hline - Argenteuil & $43 \%$ & 34113 & 3520 & 3441 & 123 & 77 \\
\hline - Bezons & $44 \%$ & 9423 & 1040 & 980 & 36 & 25 \\
\hline - Garges les Gonnesses & $34 \%$ & 12842 & 820 & 2640 & 29 & 75 \\
\hline - Goussainville & $58 \%$ & 7940 & 1349 & 1464 & 47 & 33 \\
\hline - Persan & $36 \%$ & 3402 & 2645 & 1251 & 93 & 14 \\
\hline - Saint Ouen l'Aumône & $43 \%$ & 6101 & 553 & 927 & 19 & 16 \\
\hline - Sarcelles & $33 \%$ & 17607 & 1237 & 1407 & 43 & 42 \\
\hline - Villiers le Bel & $39 \%$ & 9102 & 656 & 1182 & 23 & 45 \\
\hline Total & - & - & 11820 & 13291 & 414 & 327 \\
\hline
\end{tabular}

(1) (2) : INSEE CENSUS 1990

(3) : (1)x (2)x MWP for the city

(4) (6) : Financial appendix : Town contract 1994-1998 Sources : Mission-Ville Département du Val d'Oise

(5) : (3)x 0.035 